\title{
Development of Mungbean Yellow Mosaic Virus (MYMV) Resistant Genotypes in Greengram through Introgression of Wild Genotypes
}

\author{
M. Pandiyan*, A. Krishnaveni, P. Sivakumar, C. Sivakumar, M. Vaithilingan, \\ E. Jamuna, V. Radhakrishnan, B. Sivakumar and P. Senthilkumar
}

Plant Breeding and Genetics, Agricultural College Research Institute, Tamil Nadu Agricultural University, Vazhavachanur - 606 753, Thiruvannamalai, India

*Corresponding author

Keywords

Greengram,

MYMV resistance

Rice bean

derivatives,

Introgression

Article Info

Accepted:

26 May 2020

Available Online:

10 June 2020

\section{A B S T R A C T}

Two hundred and twenty-five $F_{2}$ derivatives of a greengram crossed between the MMYMV susceptible genotype $\operatorname{VRM}(\mathrm{Gg}) 1$ and wild Vigna species Vigna umbellata of Ricebean resistant genotypes were taken for the MYMV screening study for which the variety CO-5 greengram was used as susceptible check variety. Augmented design was imposed in the trial for test verifies the MYMV introgrossed lines of greengram derivatives. Out of 225 introgressed lines studied, the result indicated that 18 green gram genotypes viz., P- 8, P- 18, P- 30, P- 45, P- 53, P- 62, P- 72, P- 88, P- 103, P- 113, P- 124, P- 135, P- 149, P- 166, P- 174, P- 183, P- 207, P- 214 shown the negative reaction for MYMV for VMGG012 x VRM (Gg)1 greengram cross derivatives lines showed complete resistance to MYMV while other entries showed 16 percent to 100 percent MYMV infection.

\section{Introduction}

Greengram is one of the most important pulse crops consumed by the whole world through which cheapest protein get into the body for their growth and development finally good health. The yield is reduced upto 80 percent by devasting disease of Mungbean Yellow Mosaic Virus (MYMV). All over the world mungbean is not having complete resistant due seasonal and geographical variation. To generate durable resistance into the greengram improvement by using wild Vigna species. In wild Vigna species like Vigna umbellata (Rice bean) is having 100 percent MYMV resistant. Vigna umbellata is only durable donor for MYMV resistant which is included for greengram improvement.

The aim of the study is to develop MYMV resistant geneotypes in greengram crossed with rice bean resistant genotypes. To overcome the susceptibility through this crosses combination wild Vigna species. 


\section{Materials and Methods}

Two hundred and twenty- five F2 genotypes of greengram -VRM(Gg)1 (MYMV susceptible donor) with wild (Rice bean resistant donor) cross derivatives taken for the MYMV screening. All 225 plants were raised in single plant covering both side male and female parents were sown at Agricultural Research Station, TNAU, Virinjipuram, Vellore. The spacing adopted for the plant to plant was $30 \times 10 \mathrm{~cm}$. Row to row $50 \mathrm{~cm}$ was maintained. Every ten rows or genotypes, variety $\mathrm{Co} 5$ greengram susceptible check considered as one block (total 22 blocks) was raised to monitor the MYMV resistant genotypes in F2 segregants. The observation was taken in leaf area affected in a plant. Augmented design imposed in the trial for test verify the introgrossed lines of greengram This interspecific cross and their parent's resistance study was carried out. The disease intensity was recorded by observing the percentage of infected plants to the total number of plants and assigned a rating scale. The rating was done as followed by Singh et al., (1988) and greengram is concern for this study only two category is followed zero percent infected and more than zero percent infected. Zero percent infection is considered to be - and above zero percent MYMV infection is considered to be + since there no stability of MYMV infection in greengram genotypes having seasonal variation.

\section{Results and Discussion}

In the $F_{2}$ generation of interspecific crosses between greengram and rice bean, sufficient plant population of 225 plants recovered. The disease score was recorded for each ten rows. Among the 22 blocks genotypes, 18 genotypes or rows only exhibited the 100 per cent resistance to MYMV namely plant no $8,18,30 \quad 45, \quad 53, \quad 62, \quad 72,88, \quad 103$,
$113,124,135,149,166,174,183,207$ and 214 was marked as + while severe infection (100 per cent) and lowest infection below 1 was observed in the susceptible lines marked as in Table 1. In a particular season a single plant affected below 0.1 percent infection is considered to be probability of MYMV susceptibility in subsequent season since, greengram showing seasonal variability for MYMV resistance. One season one genotype showing resistance and same genotypes showing susceptibility to subsequent season. In this situation exploring the complete resistant genotypes is required that means 0.0 percent MYMV infection lines may be selected for future crop improvement programme such genotypes used as MYMV donor .

The present investigation is to assess MYMV resistant potentiality in the interspecific $\mathrm{F}_{2}$ population of (VMGG 012-05 x VGGru1) $\mathrm{x}$ V.umbellata derivatives. Mung Bean Yellow Mosaic Virus incidence of MYMV varied from 0.00 to 95.00 per cent among the 215 plants. The accessions were grouped based on the reaction of MYMV present in rows (population) and complete resistant reaction of MYMV by its expression. 100 per cent no incidence was taken as complete resistant and above 0.1 percent infections that is lowest incidence to highest 100 percent incidence considered to be susceptible genotypes. The disease intensity was recorded by observing the percentage of infected plants to the total number of plants and assigning a rating scale. Among the parents V. umbellata had a score 0 with rating of 1 indicated as resistance to MYMV where as Vigna radiata VMGG012005 had susceptible score 25 percent. The recombinants of segregating genotypes in $\mathrm{F} 2$ generation involving $V$. radiata $x \quad V$. umbellata 18 entires found as immune to MYMV while other row or genotypes showed moderate resistant to susceptible. 
Table.1 MYMV reactions for VMGG012 X VGG ru 1 cross derivatives

\begin{tabular}{|c|c|c|c|c|c|}
\hline Plant Name & $\begin{array}{c}\text { MYMV } \\
\text { REACTION }\end{array}$ & Plant Name & $\begin{array}{c}\text { MYMV } \\
\text { REACTION }\end{array}$ & Plant Name & $\begin{array}{c}\text { MYMV } \\
\text { REACTION }\end{array}$ \\
\hline P1 & + & P41 & + & P81 & + \\
\hline P2 & + & $\mathrm{P} 42$ & + & P82 & + \\
\hline P3 & + & $\mathrm{P} 43$ & + & P83 & + \\
\hline P4 & + & P44 & + & P84 & + \\
\hline P5 & + & $\mathrm{P} 45$ & - & P85 & + \\
\hline P6 & + & P46 & + & P86 & + \\
\hline P7 & + & P47 & + & P87 & + \\
\hline P8 & - & P48 & + & P88 & - \\
\hline P9 & + & P49 & + & P89 & + \\
\hline P10 & + & P50 & + & P90 & + \\
\hline P11 & + & P51 & + & P91 & + \\
\hline P12 & + & P52 & + & P92 & + \\
\hline P13 & + & P53 & - & P93 & + \\
\hline P14 & + & P54 & + & P94 & + \\
\hline P15 & + & P55 & + & P95 & + \\
\hline P16 & + & P56 & + & P96 & + \\
\hline P17 & + & P57 & + & P97 & + \\
\hline P18 & - & P58 & + & P98 & + \\
\hline P19 & + & P59 & + & P99 & + \\
\hline P20 & + & P60 & + & P100 & + \\
\hline P21 & + & P61 & + & P101 & + \\
\hline P22 & + & P62 & - & P102 & + \\
\hline $\mathbf{P} 23$ & + & P63 & + & P103 & + \\
\hline P24 & + & P64 & + & P104 & + \\
\hline P25 & + & P65 & + & P105 & + \\
\hline P26 & + & P66 & + & P106 & + \\
\hline P27 & + & P67 & + & P107 & + \\
\hline P28 & + & P68 & + & P108 & + \\
\hline P29 & + & P69 & + & P109 & + \\
\hline P30 & - & P70 & + & P110 & + \\
\hline P31 & + & P71 & + & P111 & + \\
\hline P32 & + & P72 & - & P112 & + \\
\hline P33 & + & P73 & + & P113 & + \\
\hline P34 & + & P74 & + & P114 & + \\
\hline P35 & + & P75 & + & P115 & + \\
\hline P36 & + & P76 & + & P116 & + \\
\hline P37 & + & P77 & + & P117 & + \\
\hline P38 & + & P78 & + & P118 & + \\
\hline P39 & + & P79 & + & P119 & + \\
\hline
\end{tabular}




\begin{tabular}{|c|c|c|c|c|c|}
\hline P40 & + & P80 & + & P120 & + \\
\hline P121 & + & P161 & + & P201 & + \\
\hline P122 & + & P162 & + & P202 & + \\
\hline P123 & + & P163 & + & P203 & + \\
\hline P124 & - & P164 & + & P204 & + \\
\hline P125 & + & P165 & + & P205 & + \\
\hline P126 & + & P166 & - & P206 & + \\
\hline P127 & + & P167 & + & P207 & - \\
\hline P128 & + & P168 & + & P208 & + \\
\hline P129 & + & P169 & + & P209 & + \\
\hline P130 & + & P170 & + & P210 & + \\
\hline P131 & + & P171 & + & P211 & + \\
\hline P132 & + & P172 & + & P212 & + \\
\hline P133 & + & P173 & + & P213 & + \\
\hline P134 & + & P174 & - & P214 & - \\
\hline P135 & - & P175 & + & P215 & + \\
\hline P136 & + & P176 & + & & \\
\hline P137 & + & P177 & + & & \\
\hline P138 & + & P178 & + & & \\
\hline P139 & + & P179 & + & & \\
\hline P140 & + & P180 & + & & \\
\hline P141 & + & P181 & + & & \\
\hline P142 & + & P182 & + & & \\
\hline P143 & + & P183 & - & & \\
\hline P144 & + & P184 & + & & \\
\hline P145 & + & P185 & + & & \\
\hline P146 & + & P186 & + & & \\
\hline P147 & + & P187 & + & & \\
\hline P148 & + & P188 & + & & \\
\hline P149 & - & P189 & + & & \\
\hline P150 & + & P190 & + & & \\
\hline P151 & + & P191 & + & & \\
\hline P152 & + & P192 & + & & \\
\hline P153 & + & P193 & + & & \\
\hline P154 & + & P194 & + & & \\
\hline P155 & + & P195 & + & & \\
\hline P156 & + & P196 & + & & \\
\hline P157 & + & P197 & + & & \\
\hline P158 & + & P198 & + & & \\
\hline P159 & + & P199 & + & & \\
\hline P160 & + & P200 & + & & \\
\hline
\end{tabular}

+ indicates MYMV infection, - indicates MYMV complete no infection 
Similar result was reported by Nath (1994) and Gupta (2003), (Pandiyan et al., 2007). The genotypes grouped into resistant may be further used in MYMV resistance breeding programme. Balaji et al., (2004) revealed the result as that of present study for agroinoculation in mungbean.

The Virus resistance and gene silencing in plants infected with begomovirus is derived from V.umbellata resistant source derived into derivatives of greengram and ricebean crosses (Dhakar, et al., 2010) as that of present result. Resistance to Mung bean yellow mosaic virus, phenotypic characters and yield components in urd bean the present study obtained in green gram (Kang et al., 2005). Genetics of plant virus resistance explained the genetical reaction agree with present study. Karthikeyan et al., (2012) obtained the similar results supported to the present study support for greengram Mungbean Yellow Mosaic Virus (Karthikeyan et al., 2014).

Mungbean Yellow Mosaic Virus (MYMV) resistant geneotypes derived from intraspecific crosses agree with interspecific crosses of mungean with rice bean. Mariyammal et al., (2019) studied the same genotypes of population for bruchids resistant which was developed for MYMV resistant study in mungbean and umbellata crosses (Pandiyan et al., 2005). Cross between V.radiata $x$ V.umbellata for MYMV resistant geneotypes Cytological irregularities happened as the same result obtained in this study. Pandiyan et al., (2006) reported that the Mungbean Yellow Mosaic Virus Resistance in Vigna species agreed with same kind of result obtained.

Pandiyan et al., (2018) in blackgram same types of result obtained in green gram. Selvi, et al., (2006) reported the similar result in greengram (Singh et al., 1988). reported Multiple disease resistance in mung bean with special emphasis on mung bean yellow mosaic virus (Sudha et al., 2013 and 2013 b). Inheritance studies regarding mungbean yellow mosaic virus (MYMV) in inter and intra specific crosses of mungbean (Vigna radiata) is endorse with present study results (Sudha et al., 2015).

Vigna species resistance to mungbean yellow mosaic virus in mungbean conferring study also similar to present study. The hybrids grouped under resistant may be subjected further screening in subsequent generation. Even in the smaller population of $F_{2}$ segregants, there was resistance reaction registered by V.radiata $x \quad V$. umbellata reported by Pandiyan et al., (2020) hence selection for resistance may be employed at later generation when plant population is high.

The green gram genotypes viz., $\mathrm{P}-8, \mathrm{P}-18, \mathrm{P}-$ 30, P- 45, P- 53, P- 62, P- 72, P- 88, P- 103, P- 113, P- 124, P- 135, P- 149, P- 166, P- 174, P- 183, P- 207, P- 214 for MYMV reactions for VMGG012 X VRM (Gg)1 greengram cross derivatives can be utilized for different breeding programmes to develop a variety resistant to Mungbean yellow mosaic virus. The greengram gentotypes seeds can be preserved for the future plant breeding work.

\section{References}

Balaji,VR Vanitharani,AS, Karthikeyan S, Anbalagan K and Veluthambi,K. 2004. Infectivity analysis of two variable DNA B components of Mungbean yellow mosaic virus-Vigna Vigna mungo and Vigna radiata. J. Biosci., 29: 297-308.

Dhaka K, Gupta VK, Rathore MS and Gaur RK. 2010. Virus resistance and gene silencing in plants infected with begomovirus. J. Applied Sci., 10: 17871791. 
Gupta OM. 2003. Resistance to Mung bean yellow mosaic virus, phenotypic characters and yield components in urd bean. Indian Phytopathology, 56(1):110 -111 .

Kang, B.C., I. Yearn and M.M. Jahn, 2005. Genetics of plant virus resistance. Ann. Rev. Phytopathol., 43: 581-621.

Karthikeyan A, Shobhana VG, Sudha, Raveendran M, Senthil N, Pandiyan M and Nagarajan P .2014. Mungbean yellow mosaic virus (MYMV): a threat to green gram (Vigna radiata) production in Asia. International journal of pest management .60(4), 314324.

Karthikeyan A, Sudha M, Senthil N, Pandiyan $M$, Raveendran $M$ and Nagarajan $P$ (2012). Screening and identification of random amplified polymorphic DNA (RAPD) markers linked to mungbean yellow mosaic virus (MYMV) resistance in mungbean (Vignaradiata (L.) Wilczek).Archives of phytopathology and plant protection. 45(6), 712-716.

Mariyammal I, DevinaSeram, Santhi Madhavan, Samyuktha Adhimoolam Karthikeyan, Manickam Dhasarathan, Jayakodi Murukarthick, John Samuel Kennedy, Devarajan Malarvizhi ,TaeJin Yang, Muthaiyan Pandiyan and Natesan Senthil (2019). QTL mapping in Vigna radiata $\times$ Vigna umbellata population uncovers major genomic regions associated with bruchid resistance. Molecular Breeding, 39(7), 110.

Nath PD. 1994. Effect of sowing time on the incidence of yellow mosaic virus disease and whitefly population on greengram. Ann. Agric. Res., 15 (2): $174-177$.

Pandiyan, M., A. Karthikeyan, N. Senthil, M, Sudha, C. Sivakumar, A. Krishnaveni, V. Arunkumar, V. Paramasivam and M.
Vaithiyalingan 2020. Development of Mungbean Yellow Mosaic Virus Resistant Genotypes in Mungbean through Interspecific Crosses of Wild Vigna Species. J. Pl. Sci Current Research P. No 1-8, 4(011).

Pandiyan M, Geetha S, Gnanamalar RP, Packiaraj D, Mahalingam A, Sassikumar D and Satya VK.2018. Research Article A new high yielding MYMV disease resistant blackgram variety VBN 8. Electronic Journal of Plant Breeding, 9(4), 1272-1279.

Pandiyan M, Subbulakshmi B, Alice D, Ramanathan SP and Jebaraj S .2006 b. Mungbean Yellow Mosaic Virus Resistance in vigna species, International Journal of Mendel. 23 (34), 99-100.

Pandiyan M, Subbulakshmi B, Kumar M and Jebaraj S. 2005. Cytological Studies in Vigna species, International Journal of Mendel.22 (1-2)41-42

Selvi R, Muthiah AR, Manivannan N, Raveendran TS, Manickam A. and Samiyappan R. 2006. Tagging of RAPD marker for MYMV resistance in mungbean (Vigna radiata L.) Wilczek). Asian J. Plant Sci., 5: 277-280.

Singh GS, Kappor and K. Singh. 1988. Multiple disease resistance in mung bean with special emphasis on mung bean yellow mosaic virus. In: Shanmugasundaram, S. (ed) Mung bean, proceedings of the second International symposium on Mung bean, Shanhua, Asia Vepeksu research and Development centre. Tainan, Taiwan, 290-296.

Sudha M, Anusuya P, Mahadev NG, Karthikeyan A, Nagarajan P, Raveendran M, Senthil N, Pandiyan M, Angappan $\mathrm{K}$ and Balasubramanian $\mathrm{P}$. 2013a. Molecular studies on mungbean (Vigna radiata (L.) Wilczek) and ricebean (Vigna umbellata (Thunb.)) 
interspecific hybridisation for Mungbean yellow mosaic virus resistance and development of speciesspecific SCAR marker for ricebean. Archives of phytopathology and plant protection. 46(5), 503-517.

Sudha M, Karthikeyan A, Anusuya P, Ganesh NM, Pandiyan $M$, Senthil $N$ and Angappan K. 2013b. Inheritance of resistance to mungbean yellow mosaic virus (MYMV) in inter and intra specific crosses of mungbean (Vigna radiata). American Journal of Plant Sciences.4(10), 1924

Sudha M, Karthikeyan A, Shobhana VG, Nagarajan P, Raveendran M, Senthil N, Pandiyan M and Bharathi M. 2015. Search for Vigna species conferring resistance to mungbean yellow mosaic virus in mungbean. Plant Genetic Resources, 13(2), 162-167.

\section{How to cite this article:}

Pandiyan, M., A. Krishnaveni, P. Sivakumar, C. Sivakumar, M. Vaithilingan, E. Jamuna, V. Radhakrishnan, B. Sivakumar and Senthilkumar, P. 2020. Development of Mungbean Yellow Mosaic Virus (MYMV) Resistant Genotypes in Greengram through Introgression of Wild Genotypes. Int.J.Curr.Microbiol.App.Sci. 9(06): 3787-3793.

doi: https://doi.org/10.20546/ijcmas.2020.906.449 